\title{
Retrospektywne spojrzenie na przemoc rówieśniczą w szkole ${ }^{2}$
}

\begin{abstract}
Research on bullying in schools (1) are taken mainly in the quantitative methodology and (2) are conducted mainly on the regular basis in order to diagnose the phenomenon, evaluating its size and severity, as well as its determinants. The main aim of article is to present results of retrospective study on the experience of peer violence (e.g. the bully, bullied and bystander) at school (primary, middle and high school), with a particular focus on written statements of respondents. The data source was autobiographical memory of young adults. The study was conducted in the current academic year 2014/2015 among pedagogy students of the specialties of teacher education.

As a result, the retrospective qualitative data about school experience of young adults were collected. Accept descriptions revealed a variety of personal experiences of respondents associated with peer violence at school, mainly from the perspective of its bystanders and victims. Data also provide a unique account of how adults view and perceived their school experiences.
\end{abstract}

1 Aleksandra Tłuściak-Deliowska, Katedra Dydaktyki, Wydział Nauk Pedagogicznych, Akademia Pedagogiki Specjalnej im. Marii Grzegorzewskiej w Warszawie, Polska, adeliowska@aps.edu.pl.

2 Artykuł stanowi rozszerzoną wersję referatu, o tym samym tytule, zaprezentowanego podczas IV Transdyscyplinarnego Sympozjum Badań Jakościowych, Poznań, 27-29.05.2015.

Artykuł przygotowano w ramach projektu BSTM 6/14 - I WNP realizowanego w Akademii Pedagogiki Specjalnej im. Marii Grzegorzewskiej w Warszawie, kierownik projektu: dr Aleksandra Tłuściak-Deliowska. 
The collected material also allowed to multi-faceted analysis of bullying, taking into account such aspects as: factors of becoming a victim, characteristics of the bully, whether the teachers intervention.

\section{Key words:}

aggression, violence, bullying, aggression at school, bullied, bully, teacher, retrospective study

\section{PRZEMOC RÓWIEŚNICZA W SZKOLE}

Agresja i przemoc w szkole mają różne oblicza. Każda forma zachowania, której celem jest wyrządzenie szkody fizycznej lub psychicznej jednostce lub innemu obiektowi, jest postrzegana jako agresja (Aronson, 2009, s. 250). W przypadku zachowania agresywnego mamy do czynienia z równowagą w sile psychicznej lub fizycznej pomiędzy osobami w nią zaangażowanymi. Natomiast o przemocy można mówić w sytuacji nierównowagi sił. Specyficznym jej rodzajem w szkole jest bullying (dręczenie, nękanie). Określany jest on jako powtarzające się wrogie, intencjonalne negatywne działanie sprawcy/sprawców wobec ofiary, która nie jest w stanie z jakichś powodów sama się obronić (Olweus, 2007, s. 21). Zatem na przemoc rówieśniczą w szkole składa się kompleks różnych zachowań przy jednoczesnym spełnieniu trzech warunków, którymi są: (1) intencjonalność, czyli sprawca podejmuje agresywne działanie celowo, z zamiarem skrzywdzenia; (2) nierównowaga sił, co oznacza, że sprawca jest silniejszy od ofiary pod względem fizycznym, psychicznym lub liczebnościowym (przewaga może być prawdziwa bądź postrzegana), oraz (3) powtarzalność zachowań w czasie - zachowanie agresywne nie jest jednorazowym incydentem, lecz sprawca dręczy ofiarę przez jakiś czas. Przemoc rówieśnicza może przybierać różne formy, m.in. werbalną fizyczną czy relacyjną (por. Salmivalli, 2010). Bullying ma negatywny wpływ na rozwój uczniów oraz ich dalsze życie. Chodzi tutaj nie tylko o ofiary czy sprawców, ale także o całą społeczność szkolną. Dla przemocy rówieśniczej typowy jest bowiem jej wyraźnie społeczny charakter. Oznacza to, że prześladowanie zazwyczaj odbywa się przy świadkach - pozostali uczniowie z klasy mają świadomość, kto się nad kim znęca, a w większości sytuacji są bezpośrednimi obserwatorami tego typu zachowań. Ponadto, każda osoba z grupy rówieśniczej, która wie o tym problemie, może pełnić jakąś rolę - wzmacniającą to zjawisko lub je ograniczającą (Salmivalli i in., 1996; Tłuściak-Deliowska, 2013). Uczniowie będący świadkami przemocy rówieśniczej mogą (1) dołączyć do agresora i aktywnie pomóc mu znęcać się nad ofiarą (są to 
tzw. asystenci i poplecznicy sprawcy), (2) mogą wzmacniać zachowania sprawcy poprzez dopingowanie go, wyśmiewanie ofiary - takim zachowaniem wyrażają wyraźną aprobatę dla przemocy rówieśniczej, (3) uczniowie będący świadkami mogą także opowiedzieć się po stronie ofiary, aktywnie zainterweniować, stając w jej obronie lub po całym zajściu próbować ją pocieszyć, wesprzeć czy pomóc w jakiś sposób poradzić sobie z tą trudną sytuacją, (4) uczniowie mogą również stać bezczynnie i patrzeć, „gdyż coś ciekawego się dzieje” bądź (5) wycofać się poprzez oddalenie się z miejsca czy pozostanie na uboczu „w bezpiecznej odległości” (por. Tłuściak-Deliowska, 2013, s. 82-84).

\section{BADANIA NAD PRZEMOCĄ RÓWIEŚNICZĄ W SZKOLE}

Obszar ten jest przedmiotem zainteresowań badawczych już od czterech dekad i można powiedzieć, że z oczywistych względów jest zdominowany jest przez badania prowadzone na bieżąco, w czasie teraźniejszym z zastosowaniem przede wszystkim metody self-report. Podejmowane badania służą głównie diagnozie zjawiska, ocenie jego rozmiarów i nasilenia, a także czynników je warunkujących (por. Hymel, Swearer, 2015). Wszystko po to, by możliwe było opracowanie skutecznych sposobów jego ograniczania, zapobiegania i interwencji. W oparciu o dotychczasowe badania w tym obszarze można stwierdzić, że istnieje zgoda, co do częstości i form występowania przemocy w szkole, powiązań nasilenia z typem szkoły, wiekiem i płcią (por. Komendant-Brodowska, 2014, s. 42-45). Prowadzi się także badania podłużne, by móc zasadnie udzielić odpowiedzi na pytanie, jaka jest dynamika zachowań agresywnych i przemocowych wśród dzieci i młodzieży (por. np. Ostrowska, 2007).

Na podstawie przeglądu literatury przedmiotu można stwierdzić, że pod obserwacją teoretyków i badaczy szczególnie znajdują się ofiary przemocy rówieśniczej, następnie sprawcy. Ponadto większość tych prac jest spójna, co do wyodrębnianych cech sprawców i ofiar, a także czynników wyjaśniających udział ucznia w zachowaniach przemocowych (zob. np. Pufal-Struzik, 2007). Nieco mniej miejsca poświęca się świadkom tych zachowań (Tłuściak-Deliowska, 2013, Salmivalli i in., 1996).

Duża część studiów z ostatnich lat skupia się na skutkach dręczenia szkolnego dla samopoczucia, zdrowia uczniów oraz ich funkcjonowania społecznego (Rigby, 2010, s. 57). Wyniki tych badań wskazują na liczne konsekwencje interpersonalnych i społecznych form agresji i przemocy w czasie ich przejawiania, a także w dalszej perspektywie - zarówno dla stosujących ją, jak i jej podlegających. 


\section{RETROSPEKTYWNE UJĘCIE PRZEMOCY RÓWIEŚNICZEJ W SZKOLE}

Badania retrospektywne w tym zakresie są podejmowane w niewielkim stopniu. Pojedyncze studia empiryczne rozpatrujące zjawisko przemocy rówieśniczej w ujęciu retrospektywnym realizowane są w nurcie badań ilościowych, a ich głównym celem jest poznanie, jak funkcjonują dorośli, którzy kiedyś doświadczyli przemocy rówieśniczej w szkole jako ofiara. Badania tego typu przeprowadzili m.in. Schafer i współpracownicy (2004) z użyciem specjalnie skonstruowanego „Retrospective Bullying Questionnaire”. Celem tych badań było poznanie długotrwałych efektów wiktymizacji, ze szczególną koncentracją na funkcjonowaniu osoby w miejscu pracy. Okazało się, że bycie ofiarą w szkole wiązało się z negatywnym postrzeganiem samego siebie i innych (szczególnie brakiem zaufania) w dorosłości. Efekt ten był niezależny od płci, zawodu czy różnic kulturowych. Retrospektywne ujęcie przemocy rówieśniczej pojawia się także w badaniach prowadzonych w specyficznych próbach. Hugh-Jones i Smith (1999) skoncentrowali się na próbie dorosłych jąkających się osób i okazało się, że znaczna ich część doświadczyła w szkole przemocy ze strony swoich rówieśników. Rivers (2001) z kolei skupił się na szkodliwych konsekwencjach wiktymizacji szkolnej osób homoseksualnych i również wykazał tutaj istnienie istotnych związków.

\section{BADANIA WŁASNE}

Celem projektu badawczego, którego fragment wyników będzie prezentowany, było poznanie doświadczeń studentów kierunków pedagogicznych związanych z przemocą rówieśniczą na różnych szczeblach edukacji oraz ich związku z aktualnymi przekonaniami i wiedzą o tym zjawisku, a także swoją rolą w nim. Przyjmując za punkt wyjścia założenie, że postawy ukształtowane w wyniku osobistych doświadczeń są silniejsze, pewniejsze, mniej podatne na zmiany i częściej kierują naszym działaniem niż postawy wykształcone na bazie informacji z drugiej ręki (Wojciszke, 2005, s. 84), uznano, iż zasadna jest refleksja nad uprzednimi doświadczeniami studentów kierunków nauczycielskich (późniejszych pracowników szkoły) związanymi z przemocą rówieśniczą w szkole. Tym bardziej że „wielu nauczycieli nie jest świadomych faktu, że ich własne wyniesione z dzieciństwa doświadczenia i wzory relacji, wraz ze wszystkimi przeżyciami emocjonalnymi, są reaktywowane przez pewne zachowania uczniów i mają wpływ na przebieg wydarzeń”(Gebauer, 2007, s. 110).

W tym artykule zaprezentowany zostanie fragment zgromadzonego materiału empirycznego dotyczący retrospektywnego ujęcia przemocy rówieśniczej przez 
młodych dorosłych ${ }^{3}$. Pamięć autobiograficzna, do której odwołano się w badaniach, bywa określana jako procesy i mechanizmy zaangażowane w przypominanie i rozpoznawanie przez siebie zdarzeń, których się doświadczyło (Niedźwieńska, 2000, s. 112). Oprócz pamięci semantycznej, która obejmuje dane osobowe i ogólną wiedzę o świecie, wyróżnia się pamięć epizodyczną (Matuszewski, 2005, s. 170). Dotyczy ona czasu, miejsca i aspektów sytuacyjnych różnych zdarzeń. Umożliwia przywołanie zdarzeń z osobistej przeszłości osoby, które rozegrały się w określonym miejscu i czasie. Przedmiotem szczególnego zainteresowania w podjętych badaniach była pamięć zdarzeń specyficznych, bowiem doświadczenie przemocy rówieśniczej można za takie uznać. Oczywiście badania tego typu mają szereg różnych ograniczeń. Chociażby należy zdawać sobie sprawę z tego, że dane wyszukiwane w pamięci badanych mogą układać się w rozmaite konfiguracje i być obciążone różnymi „grzechami” pamięci, które mogą wyniknąć zarówno z aktualnego stanu emocjonalnego, jak i stopnia otwartości badanego, czy też ujawniania siebie innym (por. Dudzikowa, 2010, s. 27). „Opowiadając o sobie, nigdy nie relacjonuje się wszystkiego (...), a jedynie to, co się uważa za ważne i co można włączyć do narracji” (Grzegorek, 2003, s. 217). Narracje zaś są bardzo powszechnym i naturalnym sposobem dzielenia się przez ludzi swoim doświadczeniem.

\section{PROCEDURA BADAŃ}

Badania były realizowane w okresie od października 2014 do maja 2015 roku. Najpierw przeprowadzono badania pilotażowe z udziałem 53 studentów pedagogiki w celu sprawdzenia i udoskonalenia procedury badawczej. W badaniu właściwym wzięło udział 267 studentów pedagogiki specjalności nauczycielskich, z czego 97 osób (36,3\%) to studenci rozpoczynający studia pedagogiczne, 133 osoby (49,8\%) to studenci kończący studia oraz 37 uczestników kwalifikacyjnych studiów podyplomowych w zakresie przygotowania pedagogicznego $(13,9 \%)^{4}$. Średnia wieku

3 Wyniki badań dotyczące przekonań studentów pedagogiki na temat zjawiska przemocy rówieśniczej oraz relacji między doświadczeniami szkolnymi a aktualnymi ich postawami wobec tego zjawiska będą przedmiotem odrębnych tekstów.

4 Dobór próby był celowy. Wybrano studentów kierunku pedagogika, ponadto zawężono dobór do specjalności nauczycielskich. Nie wszystkie bowiem specjalności w zakresie pedagogiki dają uprawnienia do pracy w charakterze nauczyciela. Taki dobór próby wynikał z założenia zawartego w projekcie, którego tylko fragment wyników jest prezentowany w niniejszym tekście. Mianowicie tego 
badanych wyniosła 23, 41 lat ( $\mathrm{SD}=4,65)$. Badaną próbę stanowiły w większości kobiety (255; 96,2\%), co jest charakterystyczne dla zawodu pedagoga.

Respondentom podano informację, że badanie dotyczy zjawiska przemocy w szkole. Osoby, które brały udział w badaniu, zostały także poinformowane o anonimowym charakterze badań oraz o możliwości wycofania się w każdej chwili bez ponoszenia żadnych konsekwencji. Jednakże taka sytuacja nie miała miejsca. Wręcz przeciwnie, niektórzy samoistnie podkreślali, że tego typu badania są potrzebne oraz wyrazili nimi swoje zainteresowanie.

W badaniu posłużono się specjalnie skonstruowanym narzędziem pod nazwą „Retrospektywny Kwestionariusz Przemocy Rówieśniczej w Szkole”, który został opracowany w oparciu o przegląd literatury przedmiotu oraz Retrospective Bullying Questionnaire (Schafer i in., 2004). Kwestionariusz składa się z dwóch części: zamkniętej i otwartej.

Część zamknięta/ustrukturyzowana została podzielona na trzy okresy szkolne, tj. szkoła podstawowa, gimnazjum, szkoła średnia. W każdej z tych części uwzględniono ogólną ocenę swojej szkoły (spędzony w niej czas) oraz różne doświadczenia związane z przemocą rówieśniczą. W każdej części przedstawiono różne rodzaje zachowań agresywnych, np. bicie, kopanie, niszczenie przedmiotów itp. Zadanie badanego polegało na ocenie częstotliwości (od 1 - nigdy do: 5 - bardzo często), z jaką (1) spotkał się z takich zachowaniem w swojej szkole, (2) doświadczył tego typu zachowania (jak ocenia dotkliwość tych zachowań oraz kto był sprawcą) oraz (3) sam angażował się w tego typu zachowania.

Część otwarta umożliwiła sformułowanie swobodnej wypowiedzi badanego na temat przemocy rówieśniczej w szkole. Polecenie brzmiało: „Czy jest może jakaś sytuacja, zdarzenie, które związane jest z przemocą rówieśniczą z Twoich czasów szkolnych, a które najbardziej utkwiło Ci w pamięci? Jeśli istnieje taka możliwość, proszę je opisać”. Taka droga badawcza umożliwiła doraźne i szybkie wniknięcie w pamięć biograficzną studentów dotyczącą doświadczeń przemocy rówieśniczej w szkole oraz poszerzenie jej o własne spojrzenie na zdarzenia, które miały miejsce. Początkowo część otwartą potraktowano jako uzupełnienie materiału z części zamkniętej. Oczekiwano bowiem, że pojawią się tutaj jedynie egzemplifikacje różnego rodzaju przemocy szkolnej, jednakże uzyskane rezultaty okazały się być tak zróżnicowane, obszerne i bogate znaczeniowo, iż postanowiono uczynić je przedmiotem oddzielnej analizy i prezentacji. Wyniki właśnie tej części są przedmiotem niniejszego tekstu.

typu selekcja uzasadnia, przynajmniej na tym etapie, w większym stopniu trafność użycia określenia „przyszli/potencjalni nauczyciele”. 


\section{SPOSOBY ANALIZY ZGROMADZONEGO MATERIAŁU}

Na pytanie otwarte zawarte w drugiej części retrospektywnego kwestionariusza odpowiedzieli nie wszyscy badani. Jednakże otrzymano 69 obszernych opisów doświadczeń szkolnych. Materiał badawczy, który uzyskano dzięki ostatniej części kwestionariusza, to tekst pisany zawierający różne wspomnienia, narracje, opisy doświadczeń badanych związanych z przemocą rówieśniczą w szkole. Źródłem danych była tu swobodna pisemna wypowiedź, dlatego też za najwłaściwszy sposób analizowania danych uznano w tym przypadku analizę treści. Technika ta pozwala na zbadanie treści znaczących w tekstach pisanych, wydobycie systemów znaczeń, najważniejszych wątków, faktów i relacji pomiędzy nimi (Gibbs, 2011, s. 80).

Uwzględniono dwa kroki analityczne: (1) Jakiego rodzaju doświadczenia związane z przemocą rówieśniczą w szkole zostają przytoczone przez badanych? (2) W jaki sposób badani opisują, interpretują zaprezentowane doświadczenia? Na co zwracają szczególną uwagę?

Najpopularniejszym sposobem oceny tekstu jest kodowanie, czyli przypisywanie etykiet lub oznaczeń (por. Miles, Huberman, 2000, s. 60). Kategorie mogą być wyprowadzane z tekstu lub nakładane z zewnątrz, np. z literatury przedmiotu (Konarzewski, 2000, s. 166). W pracy z materiałem zastosowano oba podejścia do generowania kategorii kodowych.

W trakcie analizy zebranego materiału w kroku pierwszym stworzono listę kodów, opierając się na literaturze przedmiotu oraz na kategoriach ujętych w ustrukturyzowanej części kwestionariusza, które uwzględniały rodzaj doświadczenia: ofiara, sprawca, świadek, oraz rodzaj przemocy: fizyczna, werbalna, relacyjna.

W ramach drugiego pytania istotne było, w jaki sposób badani opisują przywołane doświadczenia. Na co zwracają szczególną uwagę? Czy starają się pokusić o analizę, np. szukając przyczyn takiego postępowania, jego konsekwencji? W tym kroku kodowanie danych podejmowane było bez uprzedniej konceptualizacji (por. Gibbs, 2011, s. 91). Po przeczytaniu dostępnych materiałów podjęto próbę wydobycia z nich tego, co jest przedmiotem opisu. 


\section{PREZENTACJA I ANALIZA UZYSKANYCH REZULTATÓW}

\subsection{RODZAJE DOŚWIADCZEŃ ZWIĄZANYCH Z PRZEMOCĄ RÓWIEŚNICZĄ WE WSPOMNIENIACH BADANYCH}

W oparciu o rekonstrukcję doświadczeń związanych z przemocą rówieśniczą w szkole dokonane przez badanych należy stwierdzić, że mieli oni doświadczenia jako świadkowie przemocy rówieśniczej, niejednokrotnie sami byli ofiarami tego typu zachowań, ale także niektórzy wspominali swoje własne zachowania agresywne wobec rówieśników.

W zgromadzonym materiale dominowały narracje z perspektywy ucznia-świadka różnych form przemocy rówieśniczej w szkole. W poniższej tabeli przedstawiono przykładowe wypowiedzi badanych ${ }^{5}$. Zostały one pogrupowane ze względu na dominujący rodzaj zaobserwowanych zachowań przemocowych.

Tabela 1. Rodzaje przemocy, których świadkami byli studenci w okresie szkolnym

\begin{tabular}{|c|c|}
\hline Rodzaj przemocy & Przykładowe wypowiedzi \\
\hline \multirow[t]{2}{*}{ fizyczna \& werbalna } & $\begin{array}{l}\text { „W czwartej klasie podstawówki jeden chłopiec obrażał innego, młod- } \\
\text { szego chłopca. (...). Pewnego dnia, gdy starszy kolega dość mocno } \\
\text { obraził młodszego kolegę, jeden z jego kolegów nie wytrzymał i ude- } \\
\text { rzył starszego kolegę w twarz, zbił mu przy tym okulary i rozpoczęła } \\
\text { się bójka, w której uczestniczyło wielu chłopców z } 2 \text { klas” (K 19l., } \\
\text { 23PE). }\end{array}$ \\
\hline & $\begin{array}{l}\text { „Kolega pokłócił się z koleżanką o krzesło przed lekcją języka pol- } \\
\text { skiego. Było to miejsce, na którym zazwyczaj siadał. Koleżanka słabo } \\
\text { widziała i chciała usiąść bliżej, wybrała akurat to miejsce, które on } \\
\text { lubił. Gdy on to zauważył, podbiegł szybko, złapał za krzesło i uderzył } \\
\text { z całej siły koleżankę w głowę (...)” (K 23l., 29PE). }\end{array}$ \\
\hline $\begin{array}{l}\text { psychiczna \& } \\
\text { werbalna }\end{array}$ & $\begin{array}{l}\text { „Wszyscy w klasie przezywali ją, ośmieszali, często wyśmiewali, } \\
\text { naśladowali jej sposób chodzenia” (K 21l., 99PE). }\end{array}$ \\
\hline \multirow[t]{2}{*}{ relacyjna } & $\begin{array}{l}\text { „(...) od początku nauki w tej klasie nie był lubiany. Był wyraźnie } \\
\text { izolowany od grupy, większość klasy w ogóle się do niego nie odzy- } \\
\text { wała. Potem doszły wyzwiska i szykany (...)” (K 22l., 93PE). }\end{array}$ \\
\hline & $\begin{array}{l}\text { „(...) obrażali je przy innych kolegach/koleżankach. Dziewczyny były } \\
\text { wyrzucone z grupy znajomych” (K 21l., 106PE). }\end{array}$ \\
\hline
\end{tabular}

5 We wszystkich wypowiedziach zachowano oryginalne słownictwo i składnię. 


\section{Rodzaj przemocy Przykładowe wypowiedzi}

fizyczna „atak z użyciem noża, uczeń I klasy po zajęciach zaatakował ucznia klasy II nożem, raniąc go w ramię - chodziło o dziewczynę” (K 23l., 123PC).

„widziałam kiedyś, jak bardzo mocno uderzył mojego kolegę w brzuch inny chłopak” (K 24l., 146PC).

Źródło: Opracowanie własne.

Jak wynika z wybranych, powyżej przytoczonych opisów, nie zawsze zachowania agresywne były „,czystą” formą jednego rodzaju przemocy. Znacznie częściej zdarzały się mieszane formy kilku kategorii przemocy. W oparciu o rekonstrukcje różnych sytuacji opisanych przez badanych można powiedzieć, że przywoływane przez nich zdarzenia miały charakter jednorazowych incydentów agresji, przy czym wówczas były to przejawy agresji fizycznej, czasami wręcz czynów przestępczych, ale w znacznej mierze działania rówieśników miały charakter systematycznego dręczenia, czyli bullyingu.

Wśród studentów, którzy wzięli udział w badaniach, znalazły się także osoby, które same doświadczyły różnych zachowań agresywnych ze strony swoich rówieśników. W tym przypadku były to doświadczenia jednorazowych incydentów przemocowych, które jednak były niezwykle upokarzające i traumatyczne:

(...) Kilka dziewczyn zaciągnęło mnie do toalety męskiej na lekcji. Było tam dwóch chłopaków z mojej klasy. Zostałam zastraszona nożem przez jednego z nich i zmuszona do seksu oralnego z drugim. Całą sytuację nagrała jedna z dziewczyn. Gdy płakałam wymiotując oni dalej nagrywali, śmiali się, nazywali mnie lachociągiem. Filmik krążył po uczniach. Sprawa została skierowana na policję, a ja na terapię dla samobójców (K 201., 4PE).

W większym jednak stopniu przywoływane przez młodych dorosłych doświadczenia wskazywały na długotrwałe dręczenie szkolne, np.:

Martyna doniosła Kalinie, że gadam na nią głupoty. Kalina niestety uwierzyła i przestała się do mnie odzywać. Z dnia na dzień było coraz gorzej, ponieważ nastawiły całą klasę przeciwko mnie i nie miałam z kim porozmawiać, siedziałam całe przerwy sama (K 20l., 13PEP).

Trzy osoby zrekonstruowały zdarzenia, w których to one zachowywały się agresywnie wobec innych. W tych wypowiedziach oprócz opisu sytuacji wystą- 
piło także uzasadnienie tego zachowania, czyli można było dostrzec próbę ich racjonalizowania. Przykładowa wypowiedź obrazująca tę sytuację:

W czasach gimnazjalnych ja sama zaczęłam bójkę, ponieważ jedna z koleżanek bardzo mnie zdenerwowała i prowokowała w łazience. Wiadomo, że dziecko w gimnazjum jest podatne na różne czynniki i zachowania (...) (K 21l., 101PE).

\subsection{WIELOASPEKTOWA CHARAKTERYSTYKA ZJAWISKA PRZEMOCY RÓWIEŚNICZEJ W SZKOLE}

Drugi krok analityczny pozwolił na wyłonienie wielu elementów i wątków związanych ze zjawiskiem przemocy rówieśniczej w szkole ${ }^{6}$. Badani w swoich narracjach poruszali m.in. problematykę uwarunkowań danego zachowania, jego konsekwencji, uczuć doświadczanych w danej sytuacji, sposobów rozwiązania/ zakończenia problemu i reakcji rówieśników oraz dorosłych. Mimo iż były to wypowiedzi z perspektywy czasu, a opisywane zdarzenia miały miejsce kilka/ kilkanaście lat temu, kwestie poruszane przez młodych dorosłych okazały się być niezwykle aktualne.

\subsubsection{Ofiary przemocy rówieśniczej}

W większości wypowiedzi badanych została poruszona kwestia czynników wskazujących, dlaczego dany uczeń był ofiarą przemocy rówieśniczej w szkole. Tego typu elementy pojawiały się w wypowiedziach badanych zarówno tych, którzy byli świadkami tych zachowań, jak i tych, którzy sami doświadczyli przemocy. W poniższej tabeli przedstawiono przykładowe wypowiedzi badanych pogrupowane ze względu rodzaj przyczyny.

Przede wszystkim najczęściej w rekonstrukcjach zdarzeń badani wskazywali na wyróżniający się wygląd, a także niepełnosprawność uczniów-ofiar. Równie często wskazywano na rodzinę jako czynnik, który powodował, że uczeń stawał się ofiarą. Te oraz inne wskazywane przez respondentów czynniki potwierdzają charakterystykę potencjalnej ofiary, która wynika z dotychczas przeprowadzonych badań w tym obszarze (Olweus, 2007, s. 67-72; Pufal-Struzik, 2007, s. 11-12).

6 Ze względu na ograniczenia techniczne i edytorskie tekstu dokonano selekcji tych wątków. W dalszej części zostaną zaprezentowane wybrane kwestie. 
Tabela 2. Czynniki stania się ofiarą

\begin{tabular}{|c|c|}
\hline Przyczyny & Przykładowe wypowiedzi \\
\hline \multirow{8}{*}{$\begin{array}{l}\text { wygląd/ } \\
\text { niepełnospraw- } \\
\text { ność }\end{array}$} & $\begin{array}{l}\text { „Ewelina wyróżniała się na tle klasy, była dość gruba, bardzo wysoka miała } \\
\text { wadę postawy, nogi skrzyżowane do środka, nosiła okulary” (K 21l., 99PE). }\end{array}$ \\
\hline & „bo miałam spodnie, które jej się nie podobały” (K 21l., 102PE). \\
\hline & „był ośmieszany i przezywany z powodu jego wagi” (K 19l., 36PE). \\
\hline & $\begin{array}{l}\text { „obrażano i szykanowano dziewczynę, która była trochę inna niż reszta } \\
\text { klasy. (...) Z punktu widzenia dzisiaj myślę, że była lekko niepełnospraw- } \\
\text { na intelektualnie” (K 21l., 102PE). }\end{array}$ \\
\hline & $\begin{array}{l}\text { „Koledzy z klasy dokuczali chłopakowi, który był chory (często podskaki- } \\
\text { wał na «niby» skakance” (K 20l., 52PE). }\end{array}$ \\
\hline & „dokuczali, gnębili ucznia z problemami psychicznymi” (K 19l., 33PE). \\
\hline & $\begin{array}{l}\text { „chłopiec był lekko opóźniony w rozwoju intelektualnym” (K 25l., } \\
\text { 91PDP). }\end{array}$ \\
\hline & $\begin{array}{l}\text { „jako dziecko byłam gruba i ubrania miałam takie, że tylko to podkreślało” } \\
\text { (K 25l., 28PEP). }\end{array}$ \\
\hline \multirow[t]{4}{*}{$\begin{array}{l}\text { rodzina/status } \\
\text { materialny }\end{array}$} & $\begin{array}{l}\text { „(...) z powodu trudnej sytuacji materialnej, nie posiadania oryginalnych } \\
\text { ciuchów. Kiedy osoby dowiedziały się, że występuje problem alkoholu też } \\
\text { to wykorzystywały przeciwko mnie i ośmieszały przed innymi” (K23 l., } \\
\text { 100PE). }\end{array}$ \\
\hline & $\begin{array}{l}\text { „(...) z niezbyt bogatej rodziny. Chłopiec miał stare, zbyt krótkie ubrania” } \\
\text { (K 22lt., 93PE). }\end{array}$ \\
\hline & $\begin{array}{l}\text { „(...) Głównie z takiego powodu, iż moi rodzice mieli mniej pieniędzy” } \\
\text { (K 19l., 17PEP). }\end{array}$ \\
\hline & $\begin{array}{l}\text { „kazał kopać jedną dziewczynę bo była z patologicznej rodziny i śmier- } \\
\text { działo od niej” (K 20l., 22PE). }\end{array}$ \\
\hline \multirow{2}{*}{$\begin{array}{l}\text { orientacja seksu- } \\
\text { alna }\end{array}$} & „kolega, który został uderzony był homoseksualistą” (K 24l., 146PC). \\
\hline & „wyzywanie na tle orientacyjnym” (M 19l., 28PE). \\
\hline religia & $\begin{array}{l}\text { „w liceum i gimnazjum problem miały osoby bardzo wierzące, które są } \\
\text { uznawane za nudne” (K 20l., 16PEP). }\end{array}$ \\
\hline brak & „(...) Ona nie miała żadnych udziałów w powodach” (K, 174PE). \\
\hline
\end{tabular}

Źródło: Opracowanie własne.

Ofiara to osoba różniąca się od innych wyglądem, bierna, spokojna, pochodząca z rodziny, w pewnym sensie, „innej” niż rodziny rówieśników.

Doświadczenie przemocy rówieśniczej nie pozostaje bez znaczenia dla młodych ludzi. Sytuacja psychologiczna ofiary przemocy jest najtrudniejsza (por. Fenik). Konsekwencje doświadczanej przemocy zależą od długości jej trwania, rozległości, a także reakcji rówieśników i nauczycieli oraz otrzymanej pomocy lub jej braku. Konsekwencje doświadczenia przemocy rówieśniczej uobecniają się bezpośrednio 
po incydencie, ale mogą też mieć charakter długofalowy. Bezpośrednio po zdarzeniu ofiary przemocy czują się poniżone, upokorzone, odczuwają smutek i lęk. Tego typu trudne emocje nieobce były badanym:

(...) lecz najgorsze było odczucie zhańbienia i niesprawiedliwości (K 23l., 190PC).

(...) bywało, że byłam odrzucana przez wszystkie koleżanki z klasy bez żadnej konkretnej przyczyny, przynajmniej nie przypominam sobie. Nie było to jednak związane z jakąkolwiek przemocą fizyczną jednak było bardzo obciążające psychicznie, jak dla takiej małej dziewczynki, jaką jest się w szkole podstawowej (K 22l., 220PC).

(...) było mi bardzo źle, nie umiałam sobie z tym poradzić, chodziłam do psychologa szkolnego, miałam wsparcie rodziców (K 20l., 13PEP).

Z czasem kształtuje się poczucie bezradności i niemocy. Gdy ofiara przemocy nie znajduje pomocy, nie otrzymuje jej od nikogo, zaczyna powoli unikać trudnych sytuacji. Może się izolować, opuszczać szkołę. W skrajnych sytuacjach doświadczenie przemocy rówieśniczej może prowadzić do myśli samobójczych i w efekcie do podjęcia prób samobójczych. Z amerykańskich badań wynika, że ofiary przemocy rówieśniczej ponad dwa razy częściej ujawniały myśli samobójcze i ponad trzy razy częściej podejmowały próby samobójcze niż ich koledzy niebędący obiektem prześladowań (Center for Disease Control and Prevention, 2009). Tego typu sytuacje także uobecniły się w wypowiedziach studentów:

(...) zostałam skierowana na terapię dla potencjalnych samobójców (K 20l., 4PE).

(...) jeden chłopiec w wieku 14 lat tego nie wytrzymał i powiesił się w stodole nie mówiąc nikomu o swoich problemach. Oczywiście winnych brak (K 23l., 51PEP).

Długofalowe skutki bycia ofiarą to obniżona samoocena i zaniżone poczucie własnej wartości, a także problemy w nawiązywaniu prawidłowych relacji społecznych:

(...) Przez to mam wiele kompleksów i jestem zamknięta w sobie (K19l., 18PE). 
Ze swobodnych wypowiedzi badanych w odniesieniu do ofiary przemocy rówieśniczej można jeszcze wywnioskować, że zazwyczaj ofiarą była jedna-dwie osoby w klasie. Garandeau i Cillessen (2006) twierdzą, że dzięki temu zastraszanie jest skuteczniejsze i mniej ryzykowne dla sprawcy. Należy pamiętać, że sprawca ma zazwyczaj poparcie aktywne lub bierne pozostałych rówieśników, a to powoduje z kolei większą koncentrację na ofierze. Gdy ofiara jest jedna, można powiedzieć, że to w niej szuka się winy, ona wyróżnia się czymś od pozostałych, zauważa się jej cechy charakterystyczne, które traktowane są jako przyczyny negatywnych zachowań wobec niej. W pewnym sensie obwinia się ofiarę za to, co się dzieje. Jeśli natomiast ofiar byłoby więcej w tej samej grupie rówieśniczej, mogłyby one wspierać się nawzajem i np. przeciwstawić sprawcy (zob. Tłuściak-Deliowska, 2014a, s. 154). Ponadto w takim przypadku to sprawca byłby raczej wyizolowany i uwaga skupiłaby się na jego cechach i na przypisaniu jemu winy. I to niejako uobecniło się w narracjach badanych.

\subsubsection{Sprawcy przemocy rówieśniczej}

Charakterystyka sprawców w nieco mniejszym stopniu była prezentowana w narracjach studentów. Zachowań agresywnych dopuszczali się zarówno chłopcy, jak i dziewczęta. W większości przyjmuje się, że dla chłopców charakterystyczna jest głównie agresja fizyczna, z kolei dziewczęta sięgają przede wszystkim po manipulowanie przyjaźniami czy obgadywanie (Gąsior, 2007, s. 73). Jednakże we wspomnieniach badanych odnotowano sytuacje, kiedy to chłopcy izolowali rówieśnika, wyśmiewali, a dziewczęta zaś brały udział w bójkach czy „współpracowały” z chłopcami, dręcząc innych. Zatem różnice płciowe w przejawianiu zachowań agresywnych jednak się zacierają. Studenci, pisząc o sprawcy, wskazywali, że był on starszy i silniejszy, np.:

silniejszy kolega bił kolegę mniej sprawnego fizycznie (ale intelektualnie był bardzo mądry) (K 19l., 9PEP).

Interesujące jest to, że badani zwracali uwagę, wyrażając przy tym zdziwienie, że zachowań agresywnych dopuszczały się całkiem miłe, „normalne” osoby, które były popularne i lubiane w klasie:

zapamiętałam to, gdyż osoby, które znęcały się nad chłopcem były zazwyczaj całkiem miłymi osobami, nie przejawiającymi agresji, a część nawet dobrymi uczniami (K 22l., 93PE). 
„przywódca klasowy” to zobaczył i namówił chłopaków, że po lekcjach mi się dostanie (K27l., 124PC).

często osoby, które były „gwiazdami klasowymi” wyśmiewały te trzymające się na uboczu (K 19l., 9PEP).

Początkowo uważano, że sprawcy szykan są raczej przeciętnie popularni lub plasują się pod tym względem nieco poniżej średniej (Olweus, 2007, s. 74). Jednak z czasem, w efekcie prowadzenia kolejnych badań w tym zakresie, stwierdzono, że wcale tak nie jest (Salmivalli i in., 1996). Okazuje się, że sprawcą zachowań agresywnych może być osoba lubiana i popularna w klasie. Wspomnienia badanych także wskazują na nieco inny obraz sprawcy. Być może ich zdziwienie wynika z powszechnie panującego przekonania, że zachowań agresywnych skojarzonych głównie z agresją fizyczną dopuszczają się osoby z „marginesu społecznego”, z rodzin patologicznych, mające problemy itp. Tymczasem wychodzi na jaw, że sprawcy zajmują wysoką pozycję społeczną w grupie rówieśniczej. Są popularni, pewni siebie i dominujący. Osoba ciesząca się poważaniem w klasie ma mniejszą szansę, by stać się ofiarą szykan. Poza tym siła psychiczna ułatwiałaby efektywną obronę. Niestety, taki stan rzeczy może powodować akceptację dla agresywnych zachowań. Zachowanie uczniów popularnych staje się często zachowaniem normatywnym w danej grupie uczniów. Z badań Dijkstra, Lindenberga i Veenstry (2008) wynika, że w tych grupach rówieśniczych, w których uczniowie popularni angażowali się w dużym stopniu w przemoc rówieśniczą, dręczenie szkolne stało się zachowaniem akceptowalnym.

\subsubsection{Reakcje uczniów-świadków na przemoc rówieśniczą}

Przemoc rówieśnicza jest zjawiskiem o złożonym społecznym charakterze, jak zaznaczono to już wcześniej, charakterystyczna dla niego jest obecność świadków, którzy widzą lub wiedzą o tym zjawisku i którzy mogą w takiej sytuacji zachować się na różne sposoby. Szkolna agresja odbywa się zwykle na oczach innych uczniów. Potwierdzają to wcześniej przytoczone wypowiedzi, w których studenci opisywali zdarzenia, których byli bezpośrednimi obserwatorami. Oprócz tego w niektórych opisach zdarzeń szkolnych studenci rekonstruowali zachowania tych świadków, w tym swoje. Tutaj, po pierwsze, sygnalizowany był widoczny brak reakcji ze strony rówieśników:

(...) dwóch chłopców z gimnazjum strasznie dotkliwie zaczęli się bić a reszta ich kolegów stała obok, kibicowała sobie nawzajem i nie było żadnej reakcji 
z ich strony. Jedynie podziwiali. Ja chodziłam wtedy do podstawówki (K 20l., 31PEP).

W tej wypowiedzi pojawiło się na końcu usprawiedliwienie braku działania, bowiem osoba stwierdza, że była wtedy w szkole podstawowej, a zatem można się domyślić, że była słabsza od napastników i jej interwencja zapewne nie przyniosłaby oczekiwanego rezultatu. Inną możliwością uzasadnienia braku reakcji jest stwierdzenie, że zachowanie rówieśników jest niegroźne:

W gimnazjum wyśmiewali się z jednej koleżanki, która słabiej sobie radziła, rzucali w nią kredą, raz pobrudzili ubranie. Ogólnie ją lubili, ale znaleźli „kozła ofiarnego”, ja uważałam to za głupie żarty. Nigdy na poważnie nie chcieli jej skrzywdzić (K 28l., 136PC).

Powyższa wypowiedź zwraca uwagę na dwie kwestie. Po pierwsze, jest to wyraźnie zaznaczona perspektywa świadka, który dokonuje oceny zaobserwowanego zdarzenia jako sytuacji niezagrażającej nikomu, nie przypisując agresywnych intencji sprawcom. Tak jakby możliwe było „skrzywdzenie” kogoś „nie na poważnie”. Tymczasem ofiara tego typu zachowań mogła (i pewnie tak było) postrzegać je w zupełnie innych kategoriach i oczekiwać jakiegoś wsparcia czy pomocy. A zaobserwowany brak reakcji kolegów czy koleżanek mógł zwiększyć jej poczucie osamotnienia. Po drugie, widoczne jest przyzwolenie na tego typu zachowanie, bowiem dokuczanie koleżance jest postrzegane jako nikomu nie szkodząca „dobra zabawa”. Tego typu przekonania mogą jednak powodować, że uczniowie będą angażować się częściej w podobne zachowania, bowiem traktowane są one wówczas jako zachowania normatywne (Tłuściak-Deliowska, 2014a).

Niektórzy jednak - będąc bezpośrednimi świadkami przemocy rówieśniczej podejmowali interwencję z różnym skutkiem:

(...) koledzy młodszego chłopca starali się go bronić, zawsze stawali w jego obronie (K19 l., 23PE).

(...) Jedna koleżanka zaczęła szarpać drugą za włosy i uderzyła ją o parapet. Ogólnie krzyczały i biły się po twarzy. Wraz z innymi koleżankami odciągałyśmy je od siebie, ale nie działało. W końcu przestały (K 21l., 22PEP).

Pamiętam, jak kolega z klasy zorganizował „,ustawkę” z innym kolesiem - za górką. Pół szkoły poszło za nimi krzycząc „solówa, solówa” kiedy ja tam 
wpadłam mój kolega leżał na ziemi z czerwoną buzią przyduszany przez starszaka. Bałam się, że stanie się coś strasznego dlatego z rozpaczą rzuciłam się na oprawcę. Za mną poszło kilka innych osób i odciągnęliśmy „siłacza” od mojego kolegi (K 21l., 224PC).

Sam fakt reakcji uczniów na tego typu zachowanie może mieć istotne znaczenie dla ograniczenia tego typu zachowań. Z badań Pepler i Craig (1995) wynika, że wtedy gdy świadek reagował z intencją powstrzymania agresora, udało się w co najmniej 50\% przypadków zahamować dalszą przemoc. Stanowi to bowiem sygnał dla sprawców, że ich zachowanie nie jest aprobowane przez kolegów i koleżanki, czyli można to traktować w kategoriach „kary” wymierzonej przez rówieśników.

\subsubsection{Reakcje nauczycieli na przemoc wśród uczniów}

Sprawą godną uwagi jest to, że w wielu rekonstrukcjach zdarzeń badani opisywali działania nauczycieli. Gdy dochodzi do przemocy, to właśnie wychowawcy i pedagodzy są kojarzeni przez uczniów z tymi, którzy podejmą interwencję, wyjaśnią sytuację, ochronią przed jej powtórzeniem się. Zasadnicza może być sama postawa i zachowanie nauczyciela, które na co dzień obserwują uczniowie (Stephenson, Smith, 1991). Nauczyciel powinien niejako z założenia reagować szybko i skutecznie na wszelkie nieprawidłowości zaobserwowane wśród uczniów. Rekonstruując różne doświadczenia związane z przemocą rówieśniczą, studenci sporo uwagi poświęcili reakcjom nauczycieli na daną sytuację. Niestety, wypowiedzi badanych nie stawiają nauczycieli w zbyt dobrym świetle.

Badani zwracali uwagę przede wszystkim na fakt, iż reakcji nauczycieli nie było, pomimo tego że mieli oni świadomość występowania problemu. Przykładowe wypowiedzi, które na to wskazują:

Często pod oknami szkoły średniej bili się chłopcy a nauczyciele przechodzili przez tłum gapiów bez żadnej reakcji wiedząc o tym, że się biją (K 24l., 118PC).

(...) nie trafiało to do nauczycieli, a jak już to się zdarzyło to nie było reakcji z ich strony (K 19l., 36PE).

Zdecydowanie potępiam szkoły, ponieważ „pedagodzy” umywali ręce (K 27l., 53PEPn). 
Kilka dziewczyn rzucało we mnie długopisami. Nauczyciel nie reagował, więc wzięłam wszystkie długopisy i wrzuciłam je do kosza. Na przerwie te dziewczyny zaczęły mnie bić i kazały wyciągać długopisy ze śmietnika zębami. Nie zgodziłam się, co spowodowało, że zaczęły bić jeszcze bardziej. Całe zdarzenie miało miejsce w sali lekcyjnej, gdzie siedziało kilkoro uczniów i nauczyciel, ale nikt nie zareagował (K 22l., 96PE).

Reakcje nauczycieli, jeśli miały miejsce, były niesystematyczne, przypadkowe: „Nauczyciele nie zawsze na to reagowali, co było dość irytujące” (K 20l., 52PE) albo ich reakcja była niewłaściwa, nieudolna, nieskuteczna, np.:

(...) Na końcu jednak wszystko oparło się o dyrektora (gdzie ta niewinna, ofiara dostała - 100 punktów z zachowania w wyniku czego jej ocena z zachowania zmniejszyła się o 1). Agresorki do dziś śmieją się z sytuacji, że zostały bezkarne (K 20l, 227).

Chłopaki w gimnazjum często robili głupoty a później całą winę zwalali na jednego „kozła ofiarnego”. On też nie był zbyt grzeczny, więc nauczyciele karali go, nieważne czy był winny czy nie (K 21l., 38PE).

(...) ale nagle przyszła pani od plastyki i nas przegoniła, zamiast niego, mnie zaprowadziła do pani dyrektor (K 181., 6PE).

W gimnazjum, nie wiem do tej pory dlaczego podczas spotkania w sprawie wycieczki zostawiłam plecak w szatni przy w-f, ponieważ była to przerwa pomiędzy w-fami. Jedna z „przyjaciółek’ koleżanki z klasy podeszła do mnie na w-fie, zapytała czy idę na spotkanie to odpowiedziałam, że tak i poszłam. Po drugim w-fie miałam historię, rozpakowuję rzeczy, wyciągam piórnik a tam jakaś bardzo dziwna maź. Dziwne było to, że piórnik leżał pod wszystkimi książkami, ja zawsze kładłam na wierzchu. Książki i wszystko co było w plecaku było upaskudzone tą mazią. Dziewczyna, która to zrobiła stojąc pod tablicą spojrzała na mnie i zrobiła gest radości w stronę swojej innej „przyjaciółki” Sprawa szybko trafiła do dyrektora ponieważ nauczycielka od historii wiedziała o całym zajściu. (...) Musiała oddać mi swoje książki, co moim zdaniem nie było żadną karą (K 201., 7PE).

Przytoczone wypowiedzi wskazują, że nauczyciele, pomimo tego że wiedzieli o problemie niewłaściwych zachowań uczniów, nie zawsze podejmowali inter- 
wencję. Uczniowie nie mieli poczucia, że w nauczycielach mogą znaleźć oparcie w trudnych sytuacjach, gdy zaszła taka potrzeba, nie byli oni ich obrońcami czy rzecznikami ich sprawy. Można nawet odnieść wrażenie, że w tych wypowiedziach, szczególnie osób, które były ofiarami przemocy rówieśniczej, dominował ton żalu wobec nauczycieli. Rezultaty te korespondują z wynikami innych studiów empirycznych. Już nawet z pierwszych badań Olweusa (2007) nad dręczeniem szkolnym wynikało, że nauczyciele są raczej bierni, robią stosunkowo niewiele, by ograniczyć przemoc rówieśniczą w szkole. Również z autorskich wcześniejszych badań nad dręczeniem szkolnym wynika, że osoba nauczyciela jest postrzegana przez uczniów jako „mało przydatna” czy pomocna w takiej sytuacji, a przecież jest on osobą, która jest w pobliżu (Tłuściak-Deliowska, 2013). Z kolei z badań prowadzonych w ramach programu „Szkoła bez przemocy” (Giza-Poleszczuk, Komendant-Brodowska, Baczko-Dombi, 2011) wynika, że działania podejmowane przez nauczycieli, jeżeli już mają miejsce, to w ocenie uczniów raczej przynoszą więcej szkody niż pożytku, poprzez m.in. dodatkową stygmatyzację uczniów dręczonych. Jedna dziesiąta uczniów uważa, że nauczyciele udają, że nie widzą sytuacji przemocy między uczniami. Jak widać, niewiele w tym zakresie się zmieniło. Dawne sytuacje opisywane z perspektywy dorosłych osób przedstawiają się dokładnie tak, jak z perspektywy dzisiejszych uczniów. Oczywiście takie, a nie inne postępowanie nauczyciela może być wielorako uwarunkowane (zob. Tłuściak-Deliowska, 2015, s. 155-171), niemniej jednak bezsprzeczne jest to, że zachowania nauczyciela mają wpływ na uczniów, na ich postawy i dalsze zachowania.

Można oczekiwać, że obserwowane za czasów szkolnych reakcje nauczycieli (a raczej ich brak) mogą rzutować na aktualne postawy i poczucie „misji” jako przyszłego pedagoga. Nie należy bowiem zapominać o tym, że badanie było prowadzone wśród studentów pedagogiki kierunków nauczycielskich. I dokładnie to obrazuje poniższa wypowiedź:

(...) Najgorsze w tym wszystkim było to, że nauczyciele nie stanęli w naszej obronie, siedzieli cicho, jakby nigdy nic. (...) Dyrektor zrobił apel, na którym zabronił rozmów na ten temat, „lepiej o tym nie rozmawiać” - to jego słowa. Żywię ogromną urazę do nauczycieli z gimnazjum. Na szczęście prawda wyszła na jaw, rodzice wynajęli adwokata, a sędzia szybko zorientowała się, jaka jest prawda. (...) Ta sytuacja wiele mnie nauczyła, doświadczenie to wzmocniło mnie psychicznie. Jeśli będę w przyszłości nauczycielem, nigdy nie doprowadzę do takiej sytuacji! (niesłusznie oskarżona o znęcanie nad inną dziewczyną; K, 19l., 46PEP). 
Jak widać szkoły i pracujący w nich nauczyciele nie byli doskonali. Skoro nauczyciele byli nieco „niezaradni” w tej kwestii, pomocni okazywali się jednak rodzice. Choć nie zawsze ich zachowania były poprawne, np.:

(...) Tata następnego dnia poszedł do szkoły, do dyrekcji, a następnie odnalazł tego chłopaka, złapał go za skórę brzucha i rzucił o ścianę. Dali mi spokój. Wiem, że w tych czasach to ojciec pewnie miałby sprawę w sądzie, ale kiedyś były inne czasy (K 27l., 124PC).

Jednakże to oni stanowili wsparcie dla ofiar: „Gdyby nie to, że mam wspaniałych rodziców, pewnie zniechęciłabym się do szkoły” (K 27l., 86PDP).

Zazwyczaj uważa się, że uczniowie niechętnie przyznają się do tego, że są prześladowani, oni sami także twierdzą, że to, co dzieje się pomiędzy rówieśnikami, to wyłącznie ich sprawa, a nie dorosłych (por. Rigby, 2010, s. 147; Tłuściak-Deliowska 2014c, s. 22). Sporo zależy też od jakości relacji uczeń-rodzice, uczeń-nauczyciel. Jednakże gdy przemoc rówieśnicza ma charakter długotrwały, przyjmuje postać „,wyrafinowanych” zachowań, a ofiara pozostawiona jest sama sobie, prawdopodobieństwo poinformowania dorosłych wzrasta. W oparciu o przytoczone wypowiedzi można także wywnioskować, że młodzi ludzie może nie chcieli powiedzieć wprost, czy to nauczycielowi, czy rodzicom o tym, co dzieje się w klasie, szkole, ale liczyli, że dorośli sami się domyślą, zauważą, że coś jest nie tak i odpowiednio zareagują, wszakże są „pedagogami”.

\section{PODSUMOWANIE I REFLEKSCJE KOŃCOWE}

W efekcie przeprowadzonego badania zgromadzono dane jakościowe o charakterze retrospektywnym, rekonstruującym szkolne doświadczenia obecnych studentów pedagogiki. Przeprowadzone badanie dostarczyło interesujących danych, jednakże należy także mieć świadomość istnienia pewnego ograniczenia. Mianowicie, w badaniach typu self-report badacz polega na samoopisie badanego, którego wiarygodność można próbować zweryfikować i zwiększyć poprzez zastosowanie jednocześnie różnych metod badawczych. W przypadku badań o charakterze retrospektywnym to zadanie jest znacznie trudniejsze. Jednakże należy zauważyć, mając oczywiście świadomość tej bariery i zarazem z pewną dozą ograniczonego zaufania, iż zebrane opisy ujawniły interesujące, różnorodne osobiste przeżycia studentów związane z przemocą rówieśniczą w szkole i dostarczyły zarazem unikalnych relacji dorosłych już osób, zawierających rozmaite postrzeganie/rozumienie 
tego, co miało miejsce. Przywołane doświadczenia studentów związane z przemocą rówieśniczą w szkole wskazują, że wielu z nich doświadczyło przemocy jako ofiara, znaczna część była świadkami tego typu zachowań, nieliczni zachowywali się w agresywny sposób. Jednakże w większości wypowiedzi zostały poruszone także inne kwestie, dotyczące np. uwarunkowań zjawiska, jego konsekwencji czy reakcji nauczycieli. Wypowiedzi studentów stanowią przekrój różnych wątków wykazywanych w innych badaniach z tego zakresu. Niezwykle interesującą kwestią okazała się retrospektywna ocena nauczycieli. Uczniowie oczekiwali reakcji nauczycieli na zachowania agresywne i przemocowe, zarówno wówczas, gdy dotyczyły one ich bezpośrednio, ale także wtedy, gdy dotyczyły ich kolegów i koleżanek. W oparciu o przytoczone w artykule wypowiedzi można mówić o pewnej obojętności pedagogicznej wobec „łagodniejszych” form przemocy. Wobec tych „poważniejszych”, „ekstremalnych” angażowani są rodzice, władze szkolne czy aparat władzy. Na podstawie narracji badanych, a także wyników badań prowadzonych aktualnie z udziałem dzieci i młodzieży można stwierdzić, że należałoby dążyć do sytuacji, w których interwencja wobec zachowań agresywnych będzie szybka i skuteczna. Na etapie studiów trudno jest przygotować nauczycieli do wszystkich sytuacji i problemów, jakie pojawiają się w toku pracy zawodowej. Ważne jest jednak wzmacnianie tych umiejętności, które decydują o jakości procesu wychowania w szkole. Nawet jeśli nauczyciele potępiają upokarzanie i obrażanie, których dopuszczają się uczniowie, należałoby wniknąć w ukryty sens, związany z interpretacją tego zachowania przez ucznia. Przez niewystarczającą lub błędną interpretację nauczyciele mogą ponosić klęskę wychowawczą (por. Tłuściak-Deliowska, 2015). Z przywołanych w tekście wspomnień studentów wynika, że nauczyciele np. karali nie tych, którzy byli sprawcami, albo wyciągane przez nich konsekwencje nie miały dla uczniów żadnego znaczenia. Nauczyciele powinni nauczyć się właściwego interpretowania określonych zachowań swoich uczniów oraz zrozumienia wewnętrznej dynamiki klasy. „Profesjonalnie zachowuje się nauczyciel, który potrafi wczuć się w sytuację ucznia, ale nie daje się w nią wplątać” (Gebauer, 2007, s. 110).

\section{Literatura:}

Aronson, E. (2009). Człowiek istota społeczna. Warszawa: Wydawnictwo Naukowe PWN. Dijkstra, J.K., Lindenberg, S., Veenstra, R. (2008). Beyond the class norm: bullying behavior of popular adolescents and its relation to peer acceptance and rejection. Journal of Abnormal Child Psychology, 36, s. 1289-1299.

Dudzikowa, M. (2010). Poza potoczne rozumienie pamięci. W: M. Dudzikowa, R. Wawrzy- 
niak-Beszterda (red.), Doświadczenia szkolne pierwszego rocznika reformy edukacji. Studium teoretyczno-empiryczne (s. 25-27). Kraków: Oficyna Wydawnicza Impuls.

Fenik, K. (2013). Psychologiczne aspekty bullyingu: perspektywa sprawcy, ofiary i świadka. Pobrano z: http://test.ore.edu.pl/index.php?option=com_phocadownload\&view=c ategory\&id=55:profilaktyka-agresji-i-przemocy\&Itemid=1148.

Garandeau C., Cillessen, A. (2006). From indirect aggression to invisible aggression: A conceptual view on bullying and peer group manipulation. Aggression and Violent Behavior, 11, s. 641-654.

Gąsior, K. (2007). Wychowawca wobec zagrożeń związanych z przemocą rówieśniczą rozpoznawanie i zapobieganie. W: Pufal-Struzik (red.), Agresja i przemoc w szkole. Przyczyny, rozpoznawanie, zapobieganie (s. 69-85). Kielce: Wydawnictwo Pedagogiczne ZNP.

Gebauer, K. (2007). Mobbing w szkole. Warszawa: Instytut Wydawniczy PAX.

Gibbs, G. (2011). Analizowanie danych jakościowych. Warszawa: Wydawnictwo Naukowe PWN.

Giza-Poleszczuk, A., Komendant-Brodowska, A., Baczko-Dombi, A. (2011). Przemoc w szkole. Raport z badań. Pobrane z: www.szkolabezprzemocy.pl/pliki/318-sbp2011-raport-glowny-calosc.pdf.

Grzegorek, A. (2003). Narracja jako forma strukturyzująca doświadczenie. W: K. Krzyżewski (red.), Doświadczenie indywidualne. Szczególny rodzaj poznania i wyróżniona postać pamięci (s. 209-225). Kraków: Wydawnictwo Uniwersytetu Jagiellońskiego.

Hugh-Jones, S., Smith, P.K. (1996). Self-reports of short- and long-term effects of bullying on children who Stammem. British Journal of Educational Psychology, 69, s. 141-158.

Hymel, Sh., Swearer, S.M. (2015). Four decades of research on school bullying: An introduction. American Psychologist, Special Issue: School Bullying and Victimization, 4, s. 293-299.

Komendant-Brodowska, A. (2014). Agresja i przemoc szkolna. Raport o stanie badań. Analizy IBE/01/2014. Warszawa.

Konarzewski, K. (2000). Jak uprawiać badania oświatowe. Metodologia praktyczna. Warszawa: WSiP.

Maruszewski, T. (2005). Pamięć autobiograficzna jako podstawa tworzenia doświadczenia indywidualnego. W: J. Strelau (red.), Psychologia (s. 165-182). Gdańsk: GWP.

Miles, M.B., Huberman, A.M. (2000). Analiza danych jakościowych. Białystok: Trans Humana.

Niedźwieńska, A. (2000). Pamięć autobiograficzna. W: A. Gałdowa (red.), Tożsamość człowieka (s. 111-126). Kraków: Wydawnictwo Uniwersytetu Jagiellońskiego.

Olweus, D. (2007). Mobbing. Fala przemocy w szkole. Jak ją ograniczać? Warszawa: Jacek Santorski \& Co Agencja Wydawnicza.

Ostrowska, K. (2007). Rozmiary, nasilenie i rodzaje zachowań w szkole w latach 1997, 2003, 2007. Raport z badań. Warszawa.

Peer Victimization Linked to Youth Suicide, Center for Disease Control and Prevention 2009. Pobrano z: https://www.cdc.gov/violenceprevention/pdf/bullycompendium-a.pdf. Pepler, D.J., Craig, W. (1995). A peek behind the fence: Naturalistic observation of ag- 
gressive children with remote audiovisual recording. Developmental Psychology, 31, s. 548-553.

Pufal-Struzik, I. (2007). Uczeń i nauczyciel w aktach szkolnej agresji. W: I. Pufal-Struzik (red.), Agresja i przemoc w szkole. Przyczyny, rozpoznawanie, zapobieganie (s. 8-18). Kielce: Wydawnictwo Pedagogiczne ZNP.

Rigby, K. (2010). Przemoc w szkole. Jak ją ograniczać. Poradnik dla rodziców i pedagogów. Kraków: Wydawnictwo Uniwersytetu Jagiellońskiego.

Rivers, I. (2001). Retrospective reports of school bullying: Recall stability and its implications for research. British Journal of Developmental Psychology, 19, s. 129-142.

Salmivalli, C. (2010). Bullying and the peer group: A review. Aggression and Violent Behavior, 15 (2), s. 112-120.

Salmivalli, C., Lagerspetz, K., Bjorkvist, K. i in. (1996). Bullying as a Group Process: Participants Roles and Their Relation to Social Status within the Group. Aggressive Behavior, 22, s. 1-15.

Schafer, M., Korn S., Smith, P. i in. (2004). Lonely in the crowd: Recollections of bullying. British Journal of Developmental Psychology, 22, s. 379-394.

Stephenson, P., Smith, D. (1991). Why some schools don’t have bullies. W: M. Elliot (red.), Bullying: A practical guide to coping for schools (s. 133-145). Harlow, UK: Longman.

Surzykiewicz, J. (2000). Agresja i przemoc w szkole. Uwarunkowania socjoekologiczne, Warszawa: CMPP-P.

Tłuściak-Deliowska, A. (2013). Deklaracje postaw wobec przemocy rówieśniczej wśród gimnazjalistów. Psychologia Rozwojowa, 18 (3), s. 75-86.

Tłuściak-Deliowska, A. (2014a). Normy grupy rówieśniczej regulujące zachowanie się w sytuacji dręczenia szkolnego. Psychologia Wychowawcza, 6, s. 25-36.

Tłuściak-Deliowska, A. (2014b). O wykorzystaniu i użyteczności analizy sieci społecznych w badaniu przemocy rówieśniczej w szkole, Teraźniejszość - Człowiek - Edukacja, 67 (3), s. 147-159.

Tłuściak-Deliowska, A. (2014c). Przekonania normatywne gimnazjalistów dotyczące dręczenia szkolnego. Szkoła Specjalna, 1, s. 18-29.

Tłuściak-Deliowska, A. (2015). Nauczyciel a przemoc rówieśnicza wśród uczniów. Ruch Pedagogiczny, 3, s. 155-171.

Wojciszke, B. (2005). Postawy i ich zmiana. W: J. Strelau (red.), Psychologia. Podręcznik akademicki. Jednostka w społeczeństwie i elementy psychologii stosowanej (s. 79-106). Gdańsk: GWP. 